\title{
Dry care versus chlorhexidine cord care for prevention of omphalitis. Systematic review with meta-analysis
}

\author{
María Dolores López-Medina ${ }^{1}$ \\ Manuel Linares-Abad' ${ }^{1}$ \\ Ana Belén López-Araque ${ }^{2}$ \\ Isabel María López-Medina'
}

\begin{abstract}
Objective: to compare the effect of dry care and the application of chlorhexidine to the umbilical cord of newborns at risk of developing omphalitis. Method: systematic review with meta-analysis. Clinical trials comparing dry care with the application of clorexidine to evaluate omphalitis were selected. Methodological quality was evaluated using the Consolidated Standards of Reporting Trials. Results: the joint analysis of the studies shows a significant decrease in the risk of omphalitis in the chlorhexidine group compared to the dry care group ( $R R=0.58, C I: 0.53-0.64)$. However, in the analysis by subgroups, chlorhexidine umbilical cord care did not reduce the risk of omphalitis in hospital births ( $\mathrm{RR}=0.82, \mathrm{CI}: 0.64-1.05)$, in countries with a low infant mortality rate $(R R=0.8, C I: 0.5-1.28)$, or at chlorhexidine concentrations below 4\% $(R R=0.55, C I: 0.31-1)$. Chlorhexidine acted as a protective factor at a concentration of $4 \%(R R=0.58, C I: 0.53-0.64)$, when applied in cases of home births ( $R R=0.57, C I: 0.51-0.62)$, in countries with a high infant mortality rate $(R R=0.57, C I: 0.52-0.63)$. Conclusion: dry cord care is effective in countries with low infant mortality rate and in hospital births. However, $4 \%$ chlorhexidine for umbilical cord care protects against omphalitis in home births, in countries with a high infant mortality rate.
\end{abstract}

Descriptors: Umbilical Cord; Chlorhexidine; Skin Care; Infection; Meta-Analysis; Infant, Newborn.

\footnotetext{
${ }^{1}$ Universidad de Jaén, Jaén, Andalucía, Spain.

2 Complejo Hospitalario de Jaén, Andalucía, Spain.
}

\section{How to cite this article}

López-Medina MD, Linares-Abad M, López-Araque AB, López-Medina IM. Dry care versus chlorhexidine cord care for prevention of omphalitis. Systematic review with meta-analysis. Rev. Latino-Am. Enfermagem. 2019;27:e3106. [Access Available in: DOI: http://dx.doi.org/10.1590/1518-8345.2695.3106. 


\section{Introduction}

Omphalitis is an important cause of neonatal mortality and its prevention is of great importance for public health(1). The incidence of omphalitis in newborns (NB) in developed countries is $0.7 \%$, rising to $2.7 \%$ in developing countries ${ }^{(1-2)}$, and it affects both sexes equally ${ }^{(1)}$.

It is defined as a periumbilical acute bacterial infection with induration, erythema, bad smell, pain, and presenting or not association with purulent exudate at the base of the navel(3). It is peculiar at the neonatal period, and the average age for its incidence is the third or fourth day of life ${ }^{(2-3)}$.

The strategies for prevention of omphalitis are: hygiene practices at delivery, aseptic material to cut the umbilical cord and hand washing every time the cord is handled(4). In the 21 st century there have been several studies on umbilical cord (UC) care comparing different antiseptics, and several studies have shown that the hygiene habits of bathing and drying it were not associated with an increased risk of omphalitis when compared to alcohol application ${ }^{(4-6)}$. Topical triple dye is a treatment used in the United States, and there are several studies comparing the topical triple dye with alcohol application for UC care, and the results of these studies show that there are no differences between the treatment groups of omphalitis( ${ }^{7-8)}$.

There are no studies with adequate level of evidence to establish recommendations on the most effective UC care for prevention of omphalitis in NB. Thus, a systematic review was performed to answer the question: Is the application of chlorhexidine more effective than dry cord care for prevention of omphalitis? The objective was: to compare the effect of dry care and the application of chlorhexidine to the umbilical cord of newborns at risk of developing omphalitis.

\section{Method}

A systematic review with meta-analysis was carried out, for which a bibliographic search was performed in the Cochrane, Pubmed, Scopus, CINAHL, EMBASE, Cuiden and Spanish Medical Index (EMI) databases, and a reverse search with secondary recovery. The bibliographic search was carried out by January 2017, with no previous date range limit or language restriction. In order to identify the articles describing the incidence of omphalitis in NB to which dry care or chlorhexidine cord care was used for UC care, the following descriptors were used: umbilical cord care, dry care, newborn, topical umbilical cord care, chlorhexidine umbilical cord care, umbilical cord care practices, randomized controlled trial and
Clinical Trial. The following search strategy was used in the PubMed/MEDLINE database: (Umbilical cord[mh] or cords, umbilical[tiab] or umbilical cord[tiab]) and (cord care[tiab] or dry care[tiab] or dry*[tiab] or chlorhexidine[mh] or chlorhexidine cord care $[$ tiab]) and (new-born[mh] or infant[mh]) and (omphalitis[tiab]) and (clinical trial[pt]). To plan, prepare and publish the systematic review and metaanalysis, the guidelines provided by the Preferred Reporting Items for Systematic Reviews and MetaAnalyses (PRISMA) ${ }^{(9)}$ were followed.

For the selection of the studies, two authors independently assessed the inclusion of the studies identified by the search strategy. In the first phase, the articles were selected according to their title and, after reading the abstracts, those that met the inclusion criteria were selected. Subsequently, an in-depth reading was carried out and their methodological quality was assessed using the Consolidated Standards Of Reporting Trials (CONSORT)(10).

Clinical trials comparing dry care with the application of chlorhexidine solutions at all concentrations available for UC care were used as inclusion criteria. All living NB were included, without restricting the weight at birth, sex, gestational age, geographical area, level of development and delivery setting.

Using a previously developed form, two authors independently extracted the data according to: type of study, population included, length of fieldwork period, duration of follow-up, type of intervention, procedure carried out with both the dry care and the chlorhexidine cord care, and results obtained. Those authors whose articles are the subject of this study were contacted so that they could provide the data necessary for performing the meta-analysis by subgroups. A third person evaluated the discrepancies found in order to decide on the inclusion of some articles and on data extraction.

The Grading of Recommendations Assessment, Development and Evaluation (GRADE)(11) was used to evaluate the quality of the evidence, which was classified as: high, moderate, low or very low.

The results were expressed as relative risk (RR) with 95\% confidence interval. The clinical heterogeneity and the homogeneity of the population were evaluated. The statistical heterogeneity and the consistency between the results of the studies were evaluated using $\mathrm{I}^{2}$ as criterion measure. $\mathrm{I}^{2}$ values of $25 \%, 50 \%$ and $75 \%$ were used to define heterogeneity as low, moderate and high. When this criterion was higher than $50 \%$, a random effects model was applied to combine the results ${ }^{(12)}$. A sensitivity analysis of the results was carried out by performing 
several meta-analyzes sequentially, by subdividing them according to the methodological quality of the studies, the sample number and the concentration of chlorhexidine.

A subgroup analysis was performed for the data of the studies conducted with hospital and community $\mathrm{NB}$, and dividing these data by the neonatal mortality rate (NMR) of the place of origin of the study: high NMR $\geq 10$ per 1,000 live births versus low NMR $<10$ per 1,000 live births. In addition, a subgroup analysis was carried out for chlorhexidine concentrations: $4 \%$ chlorhexidine and chlorhexidine concentrations lower than $4 \%$.

For the statistical analysis, Review Manager 5.3(13) and Epidat 3.1 $1^{(14)}$ softwares were used.

\section{Results}

Figure 1 shows the process of selecting studies. The literature search found 511 articles, of which 468 were discarded after a reading of their titles. The analysis of the summaries led to exclusion of 28 through a complete reading of 15 articles, and 6 were eliminated for different reasons: chlorhexidine was not compared with dry cord care ${ }^{(15)}$; be a research

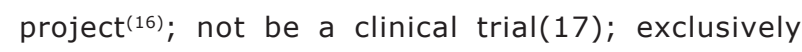
measure the time until the umbilical cord stump falls off(18-20).

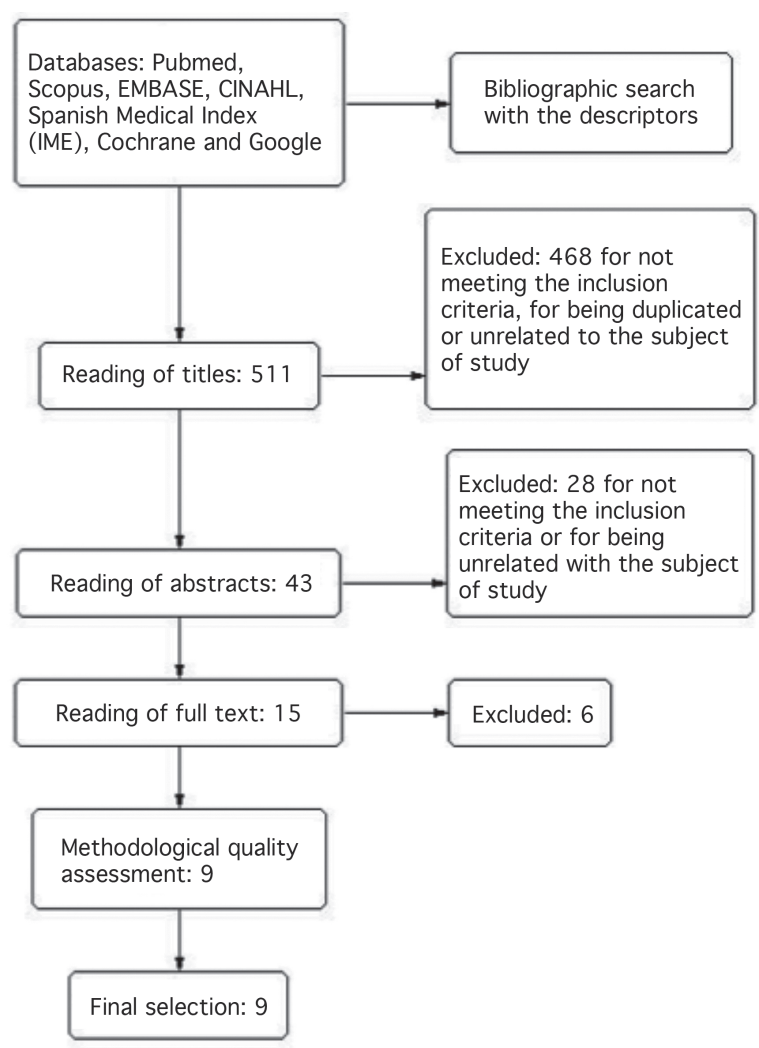

Figure 1 - Process of selecting studies

Figure 2 shows the characteristics of the sample of each study, interventions and outcome measures.

\begin{tabular}{|c|c|c|c|c|}
\hline $\begin{array}{c}\text { Author, country, } \\
\text { year }\end{array}$ & $\begin{array}{c}\text { Methods and } \\
\text { Participants }\end{array}$ & Interventions & Definitions & Monitoring, procedure and results \\
\hline $\begin{array}{l}\text { Meberg et al(21). } \\
\text { Norway, } 1985 .\end{array}$ & $\begin{array}{l}\text { Randomized } \\
\text { clinical trial. } \\
\text { Newborns }>37 \\
\text { weeks. }\end{array}$ & $\begin{array}{l}\text {-Dry care. (total } n=219 ; \\
n \text { included in the } \\
\text { analysis=219). } \\
\text {-Daily care with } 4 \% \\
\text { clorhexidine. (total } \\
n=217 ; n \text { included in } \\
\text { the analysis=217). }\end{array}$ & $\begin{array}{l}\text { There is no } \\
\text { definition }\end{array}$ & $\begin{array}{l}\text { Monitoring for } 6 \text { weeks in } 2 \text { periods. Procedure: } \\
\text { application of chlorhexidine for } 2 \text { minutes at the base } \\
\text { of the umbilical cord. Results: } \\
\text {-Bacterial infections in the first } 6 \text { weeks: } 12.9 \% \\
\text { (pemphigus: } n=52 \text {, conjunctivitis: } n=23 \text {, paronychia: } \\
n=11 \text {, omphalitis: } n=9 \text { ). } \\
\text {-Bacterial colonization: S. Aureus: } 91 \% \text { : } \\
\text { Streptococcus B: } 20 \% \text { and E. coli: } 39 \% \text {. }\end{array}$ \\
\hline $\begin{array}{l}\text { Mullany et al(22). } \\
\text { Nepal, } 2006 .\end{array}$ & $\begin{array}{l}\text { Randomized } \\
\text { clinical trial. } \\
\text { November } \\
\text { 2002-March } \\
2005 . \\
\text { Live newborns. }\end{array}$ & $\begin{array}{l}\text { Dry care (total } n=5082 \text {, } \\
\text { included in the analysis } \\
n=5021 \text { ). } \\
\text {-Water and soap (total } \\
n=5107 \text { ). } \\
-4 \% \text { chlorhexidine cord } \\
\text { care (once a day for } 10 \\
\text { days). (total } n=4924 \text {, } \\
\text { included in the analysis } \\
n=4883 \text { ). }\end{array}$ & $\begin{array}{l}\text { Omphalitis: } \\
\text { Redness extending } \\
\text { to the skin at the } \\
\text { base of the umbilical } \\
\text { cord. Pus with } \\
\text { moderate or severe } \\
\text { redness, or severe } \\
\text { redness only. } \\
\text { Severe redness with } \\
\text { pus. }\end{array}$ & $\begin{array}{l}\text { Visits: on the } 1^{\text {st }}, 2^{\text {nd }}, 3^{\text {rd }}, 4^{\text {th }}, 6^{\text {th }}, 8^{\text {th }}, 10^{\text {th }}, 12^{\text {th }}, 14^{\text {th }}, 21^{\text {st }} \\
\text { and } 28^{\text {th }} \text { days of life. } \\
\text { Procedure: homogenous groups with previous } \\
\text { hand washing; kit delivery was given and the same } \\
\text { procedure was carried out for UC care, all groups had } \\
\text { opaque plastic bottles. } \\
\text { Results: } \\
\text {-Onfalitis: the risk of infection in the chlorhexidine } \\
\text { group was } 54 \% \text { lower than the dry care group. } \\
\text {-Mortality: in comparison with the dry care group, } \\
\text { the risk of mortality was } 24 \% \text { lower than in the } \\
\text { chlorhexidine group }\end{array}$ \\
\hline
\end{tabular}

(the Figure 2 continue in the next page...) 


\begin{tabular}{|c|c|c|c|c|}
\hline $\begin{array}{c}\text { Author, country, } \\
\text { year }\end{array}$ & $\begin{array}{l}\text { Methods and } \\
\text { Participants }\end{array}$ & Interventions & Definitions & Monitoring, procedure and results \\
\hline $\begin{array}{l}\text { Kapellen et al }{ }^{(23)} \text {. } \\
\text { Germany, } 2009 .\end{array}$ & $\begin{array}{l}\text { Randomized } \\
\text { clinical trial. } \\
\text { November } \\
2003-\text { August } \\
2005 \text {. } \\
\text { Full-term } \\
\text { newborns: } \\
37-42 \text { weeks. } \\
\text { Weight greater } \\
\text { than 2500gr. }\end{array}$ & $\begin{array}{l}\text { Dry care (total } n=332 \text {, } \\
\text { included in the analysis } \\
n=332 \text { ). } \\
-1 \% \text { chlorhexidine } \\
\text { powder (once a day } \\
\text { for at least } 3 \text { days after } \\
\text { stump falls off. (total } \\
n=337 \text {, included in the } \\
\text { analysis } n=337 \text { ). }\end{array}$ & $\begin{array}{l}\text { Omphalitis: } \\
\text { erythema, edema, } \\
\text { secretion, sepsis or } \\
\text { umbilical cellulitis. }\end{array}$ & $\begin{array}{l}\text { Visits on the } 10^{\text {th }}-14^{\text {th }} \text { days after birth. } \\
\text { Procedure: Chlorhexidine application every diaper } \\
\text { change. Daily monitoring by parents with evolution } \\
\text { reporting. } \\
\text { Results: } \\
\text {-Stump fall off time: } 7.0 \pm 2.5 \text { days in the chlorhexidine } \\
\text { group and } 7.8 \pm 2.9 \text { days in the dry care group. } \\
\text { Adverse events: ulcers, granulomas, omphalitis, } \\
\text { erythema, edema, secretion. Incidence of adverse } \\
\text { events: chlorhexidine group: } 32.3 \% \text { of NB; dry care } \\
\text { group: } 44.9 \% \text {. } \\
\text {-Satisfaction with the treatment: chlorhexidine group: } \\
98.9 \% \text { were satisfied or very satisfied; dry care group: } \\
91.4 \% \text { were satisfied or very satisfied. }\end{array}$ \\
\hline $\begin{array}{l}\text { El Arifeen et al }{ }^{(24)} \text {. } \\
\text { Bangladesh, } \\
2012 .\end{array}$ & $\begin{array}{l}\text { Randomized } \\
\text { clinical trial. } \\
\text { June 2007- } \\
\text { September } \\
2009 . \\
\text { Live newborns. }\end{array}$ & $\begin{array}{l}\text { Dry care (total } \\
n=10.008, \text { included in } \\
\text { the analysis } n=9924) \text {. } \\
\text {-A single application } \\
\text { of } 4 \% \text { chlorhexidine. } \\
\text { (total } n=9423 \text { ). } \\
\text {-A daily application } \\
\text { of chlorhexidine for } 7 \\
\text { days. (total } n=10329 \text {, } \\
\text { included in the analysis } \\
n=10254 \text { ). }\end{array}$ & $\begin{array}{l}\text { Omphalitis: } \\
\text { Redness extending } \\
\text { to the skin or pus. } \\
\text { Redness extending } \\
\text { to the skin. } \\
\text { Redness with pus or } \\
\text { severe redness. } \\
\text { Severe redness with } \\
\text { pus. }\end{array}$ & $\begin{array}{l}\text { Visits: on the } 1^{\text {st }}, 3^{\text {rd }}, 6^{\text {th }}, 9^{\text {th }} \text { and } 15^{\text {th }} \text { days. Another } \\
\text { visit between on the } 28 \text { th and } 35 \text { th days. Procedure: } \\
\text { all groups used opaque plastic bottles; in the daily } \\
\text { chlorhexidine group, the solution was applied } \\
\text { once after birth, and once a day for } 7 \text { days. The } \\
\text { recommendations of the WHO were followed in the } \\
\text { dry care group. At each visit, UC condition and the } \\
\text { care procedure were checked. A sterile instrument } \\
\text { was used to cut the cord in } 93 \% \text { of NB. } \\
\text { Results: } \\
\text {-Onfalitis: when compared with the multiple } \\
\text { chlorhexidine group, the dry care group showed } \\
\text { a lower risk of redness or pus, and a lower risk of } \\
\text { severe redness with pus. } \\
\text {-Mortality: there are no statistically significant } \\
\text { differences in the relative risk of neonatal mortality } \\
\text { between multiple chlorhexidine group and the dry } \\
\text { care group }\end{array}$ \\
\hline $\begin{array}{l}\text { Soofi et al(25). } \\
\text { Pakistan, } 2012 .\end{array}$ & $\begin{array}{l}\text { Randomized } \\
\text { clinical trial. } \\
\text { January 2008- } \\
\text { June 2009. } \\
\text { Live newborns. }\end{array}$ & $\begin{array}{l}-4 \% \text { chlorhexidine for } \\
\text { cord care once a day } \\
\text { for } 14 \text { days after birth } \\
\text { and hand washing with } \\
\text { soap. (total } n=2827 \text {, } \\
\text { included in the analysis } \\
n=2214 \text { ). } \\
\text {-Dry care with previous } \\
\text { hand washing. (total } \\
n=2822 \text {, included in } \\
\text { the analysis } n=2475 \text { ). } \\
-4 \% \text { chlorhexidine } \\
\text { for cord care once a } \\
\text { day for } 14 \text { days after } \\
\text { birth without previous } \\
\text { hand washing. (total } \\
n=3131 \text { ). } \\
- \text { Control group: Care } \\
\text { without previous } \\
\text { hand washing. (total } \\
n=3106 \text { ). }\end{array}$ & $\begin{array}{l}\text { Omphalitis: } \\
\text { No omphalitis: no } \\
\text { redness, swelling } \\
\text { or pus. } \\
\text { Mild onfalitis: } \\
\text { redness, swelling, or } \\
\text { pus in the cord area. } \\
\text { Moderate onfalitis: } \\
\text { redness, swelling } \\
\text { or pus extending } \\
\text { for less than } 2 \mathrm{~cm} \\
\text { to the skin from the } \\
\text { base of the cord } \\
\text { stump. } \\
\text { Severe omphalitis: } \\
\text { inflammation } \\
\text { extending for more } \\
\text { than } 2 \mathrm{~cm} \text { from the } \\
\text { cord, with or without } \\
\text { pus. }\end{array}$ & $\begin{array}{l}\text { Visits: on the } 1^{\text {st }}, 3^{\text {rd }}, 5^{\text {th }}, 7^{\text {th }}, 14^{\text {th }} \text { and } 28^{\text {th }} \text { days. } \\
\text { Procedure: the midwives were trained, and each } \\
\text { participant was given a birth kit and hand washing } \\
\text { instructions in all groups. During the visits, care } \\
\text { performance and signs of omphalitis were observed. } \\
\text { Results: } \\
\text {-Onfalitis: the risk of omphalitis (any degree) in the } \\
\text { three treatment groups was lower than in the control } \\
\text { group. } \\
\text {-Neonatal mortality: } 29.4 \text { per } 1,000 \text { live births }\end{array}$ \\
\hline $\begin{array}{l}\text { Gathwala et al(26). } \\
\text { India, } 2013 .\end{array}$ & $\begin{array}{l}\text { Randomized } \\
\text { clinical trial. } \\
\text { June 2010- } \\
\text { November } 2011 . \\
\text { Newborns } \\
>32 \text { weeks } \\
\text { and } 1500 \mathrm{gr} \text { of } \\
\text { weight. }\end{array}$ & $\begin{array}{l}-2.5 \% \text { chlorhexidine } \\
\text { gluconate, } 3 \text { times a } \\
\text { day for } 3 \text { days. (total } \\
n=70, \text { included in the } \\
\text { analysis } n=70 \text { ). } \\
\text {-Dry care and fold the } \\
\text { diaper below the cord } \\
\text { (total } n=70, \text { included in } \\
\text { the analysis } n=70 \text { ). }\end{array}$ & $\begin{array}{l}\text { Probable sepsis. } \\
\text { Culture-proven } \\
\text { sepsis }\end{array}$ & $\begin{array}{l}\text { Monitoring at hospital admission. Procedure: dry care } \\
\text { group: UC was mantained clean and dry and the } \\
\text { diapers were folded under the umbilical stump; in the } \\
\text { chlorhexidine group, chlorhexidine was applied to the } \\
\text { UC three times a day (once per nursing shift) for } 3 \\
\text { days after the stump falls off. The cord was observed } \\
\text { twice a day for signs of omphalitis. } \\
\text { Results: } \\
\text {-Cord fall off time. In the clorhexidine care group: } \\
\text { average: } 8.92 \pm(2.77) \text {; in the dry care group: average } \\
10.31 \pm(3.23) \text {. } \\
\text {-Onfalitis: The absolute risk of sepsis proven by } \\
\text { culture was } 21.43 \% \text { and } 2.86 \% \text { in the dry care group } \\
\text { and in the chlorhexidine group, respectively. } \\
- \text { Mortality: chlorhexidine group, } n=0 \text {, dry care group, } \\
n=4 \text {. }\end{array}$ \\
\hline
\end{tabular}

(the Figure 2 continue in the next page...) 


\begin{tabular}{|c|c|c|c|c|}
\hline $\begin{array}{c}\text { Author, country, } \\
\text { year }\end{array}$ & $\begin{array}{l}\text { Methods and } \\
\text { Participants }\end{array}$ & Interventions & Definitions & Monitoring, procedure and results \\
\hline $\begin{array}{l}\text { Semrau et al(27). } \\
\text { Zambia, } 2016 .\end{array}$ & $\begin{array}{l}\text { Randomized } \\
\text { clinical trial. } \\
\text { February } \\
\text { 2011-January } \\
\text { 2013. } \\
\text { Live newborns. }\end{array}$ & $\begin{array}{l}- \text { Dry care (total } \\
n=21044 \text {, included in } \\
\text { the analysis } n=19346) \text {. } \\
-4 \% \text { chlorhexidine for } \\
\text { cord care once a day } \\
\text { for at least } 3 \text { days after } \\
\text { cord falls off. (total } \\
n=21280 \text {, included in } \\
\text { the analysis } n=18510 \text { ). }\end{array}$ & $\begin{array}{l}\text { Erythema or } \\
\text { purulent secretion. }\end{array}$ & $\begin{array}{l}\text { Visits: on the } 1^{\text {st }}, 4^{\text {th }}, 10^{\text {th }} \text {, and } 28^{\text {th }} \text { days after delivery. } \\
\text { Procedure: the mothers were previously trained on } \\
\text { the type of care; each participant was given a birth kit } \\
\text { and hand washing instructions in all groups. During } \\
\text { the visits, care performance and signs of omphalitis } \\
\text { were observed. In the chlorhexidine group, it was } \\
\text { applied once a day for at least } 3 \text { days after the cord } \\
\text { falls off, with previous instructions on how to perform } \\
\text { the care. The recommendations of the Ministry of } \\
\text { Health of Zambia were followed in the dry care group. } \\
\text { Results: } \\
\text {-Onfalitis: in the chlorhexidine group, } 4.43 \\
\text { cases/1,000 live births; in the dry care group, } 6.10 \\
\text { cases } 1,000 \text { live births. } \\
\text {-Mortality: } 14.4 \text { deaths per } 1,000 \text { live births. The } \\
\text { application of chlorhexidine was not associated with a } \\
\text { decrease in neonatal mortality }\end{array}$ \\
\hline $\begin{array}{l}\text { Sazawal et al(28). } \\
\text { Tanzania, } 2016 .\end{array}$ & $\begin{array}{l}\text { Randomized } \\
\text { clinical trial. } \\
\text { May } \\
\text { 2011-August } \\
\text { 2014. Live } \\
\text { newborns. }\end{array}$ & $\begin{array}{l}\text {-Dry care. (total } \\
n=18896, \text { included } \\
\text { in the analysis } n= \\
18896 \text { ). } \\
-4 \% \text { chlorhexidine for } \\
\text { cord care once a day } \\
\text { for at least } 3 \text { days after } \\
\text { cord falls off. (total } \\
n=18015 \text {, included in } \\
\text { the analysis } n=18015 \text { ). }\end{array}$ & $\begin{array}{l}\text { Omphalitis: } \\
\text { Redness in the skin } \\
\text { or pus. } \\
\text { Redness in the skin } \\
\text { Redness with pus or } \\
\text { severe redness. } \\
\text { Severe redness } \\
\text { with pus }\end{array}$ & $\begin{array}{l}\text { Visits: on the } 0,1^{\text {st }}, 4^{\text {th }}, 10^{\text {th }} \text { and } 28^{\text {th }} \text { days. } \\
\text { Procedure: the mothers were previously trained on } \\
\text { the type of care in both groups; each participant in the } \\
\text { chlorhexidine group was given the solution in flasks } \\
\text { for the family to apply; in the days that researches } \\
\text { were present, they performed the care. In the care } \\
\text { group, in addition to the previous instructions, it was } \\
\text { emphasized that the UC should be maintained dry. } \\
\text { During the visits, signs of omphalitis were sought. } \\
\text { Results: } \\
\text {-Onfalitis: in the chlorhexidine group: } 78.4 / 1,000 \text { live } \\
\text { births; in the dry care group: } 115.5 / 1,000 \text { live births. } \\
\text {-Mortality: in the chlorhexidine group: } 10.5 / 1,000 \text { live } \\
\text { births; in dry care group: } 11.7 / 1,000 \text { live births. }\end{array}$ \\
\hline $\begin{array}{l}\text { Gras-Le Guen et } \\
\text { al(29). } \\
\text { France, } 2017 \text {. }\end{array}$ & $\begin{array}{l}\text { Non-randomized } \\
\text { clinical trial. } \\
\text { March } \\
\text { 2011-March } \\
\text { 2012. } \\
\text { Newborns > } 36 \\
\text { weeks. }\end{array}$ & $\begin{array}{l}\text { Dry care (total } n=4294 \text {, } \\
\text { included in the analysis } \\
n=3899 \text { ). } \\
1 \% \text { chlorhexidine } \\
\text { cord care, and use of } \\
\text { alcohol until the stump } \\
\text { falls off. (total } n=4404 \text {, } \\
\text { included in the analysis } \\
n=4221 \text { ). }\end{array}$ & $\begin{array}{l}\text { Omphalitis: } \\
\text { Grade I: purulent } \\
\text { secretion from the } \\
\text { umbilical stump. } \\
\text { Grade II: cellulitis or } \\
\text { lymphangitis. } \\
\text { Grade III: } \\
\text { inflammation } \\
\text { extending into } \\
\text { subcutaneous fat } \\
\text { and deep fascia. }\end{array}$ & $\begin{array}{l}\text { Monitoring until the } 28^{\text {th }} \text { day of life. } \\
\text { Procedure: previous training to caregivers together } \\
\text { with written information. In the hospital, it was } \\
\text { checked if the learning was correct. } \\
\text { Results: } \\
\text {-Onfalitis: incidence of omphalitis in the dry care } \\
\text { group: } 0.08 \% \text {. } \\
\text {-Average stump fall off time: in the dry care group: } \\
10 \text { days (interquartile range } 8-12 \text { ). In the intervention } \\
\text { group: } 11 \text { days (interquartile range } 8-14 \text { ). } \\
\text {-Satisfaction of parents with cord care: there were no } \\
\text { statistically significant differences in the satisfaction } \\
\text { between the different groups. }\end{array}$ \\
\hline
\end{tabular}

Figure 2 - Characteristics of the studies included in the meta-analysis. Jaén, Andalusia, Spain, 2017

The meta-analysis was performed using the 9 selected studies and 118,903 NB in total, of which $50.61 \%$ underwent dry umbilical cord care $(60,182 \mathrm{NB})$. In total, there were 1,863 cases of omphalitis in both groups, and $64.03 \%$ of these cases of omphalitis belong to the dry cord care group.

Figure 3 shows the biases of the different studies included in the meta-analysis, with no study considered to be invalid.

\begin{tabular}{|c|c|c|c|c|c|c|}
\hline Study & $\begin{array}{l}\text { Allocation } \\
\text { concealment }\end{array}$ & $\begin{array}{l}\text { Randomized } \\
\text { sequence }\end{array}$ & $\begin{array}{l}\text { Blinding of } \\
\text { participants and } \\
\text { practioners }\end{array}$ & $\begin{array}{l}\text { Blinding of the } \\
\text { evaluators }\end{array}$ & Incomplete data & $\begin{array}{l}\text { Selective report } \\
\text { of results }\end{array}$ \\
\hline Meberg, 1985 & $¿ ?^{*}$ & ¿? & ¿? & ¿? & $+\dagger$ & + \\
\hline Mullany, 2006 & ¿? & + & + & + & + & + \\
\hline Kapellen, 2009 & ¿? & + & $-\ddagger$ & - & + & + \\
\hline Arifeen, 2012 & - & + & - & - & + & + \\
\hline Soofi, 2012 & + & + & + & + & + & + \\
\hline Gathwala, 2013 & + & + & + & + & + & + \\
\hline
\end{tabular}

(the Figure 3 continue in the next page...) 


\begin{tabular}{|c|c|c|c|c|c|c|}
\hline Study & $\begin{array}{l}\text { Allocation } \\
\text { concealment }\end{array}$ & $\begin{array}{l}\text { Randomized } \\
\text { sequence }\end{array}$ & $\begin{array}{l}\text { Blinding of } \\
\text { participants and } \\
\text { practioners }\end{array}$ & $\begin{array}{l}\text { Blinding of the } \\
\text { evaluators }\end{array}$ & Incomplete data & $\begin{array}{l}\text { Selective report } \\
\text { of results }\end{array}$ \\
\hline Sazawal, 2016 & + & + & - & - & + & + \\
\hline Semrau, 2016 & + & + & - & - & + & + \\
\hline $\begin{array}{l}\text { Gras-Le Guen, } \\
2017\end{array}$ & ¿? & + & - & + & + & + \\
\hline
\end{tabular}

$* i$ ? = Unknown risk, $++=$ Low risk of bias, $\neq-=$ High risk of bias

Figure 3 - Biases of the studies included in the meta-analysis. Jaén, Andalusia, Spain, 2017

Regarding the risk of omphalitis, the 9 included studies show a significant decrease in the risk of omphalitis in the chlorhexidine group compared to the dry cord care group, with a RR of 0.58 (CI: 0.53-0.64), with moderate heterogeneity $\left(\mathrm{I}^{2}=45 \%, \chi^{2}=14.51, \mathrm{p}=0.07\right)$. This may be due to the clinical heterogeneity and, therefore, a subgroup analysis was performed. The result of the Egger's test $^{(30)}$ was $0.4556(p=0.6625)$, which indicates that there is no publication bias. The data with which the meta-analysis was carried out (Figure 4) come from studies in which chlorhexidine was applied multiple times. According to the GRADE system, this level of evidence is rated as moderate. It can be seen in the tree graph (Figure 4) that four studies ${ }^{(21,27-29)}$ do not show a significant decrease in the risk of omphalitis with the use of chlorhexidine for cord care when compared with dry care.

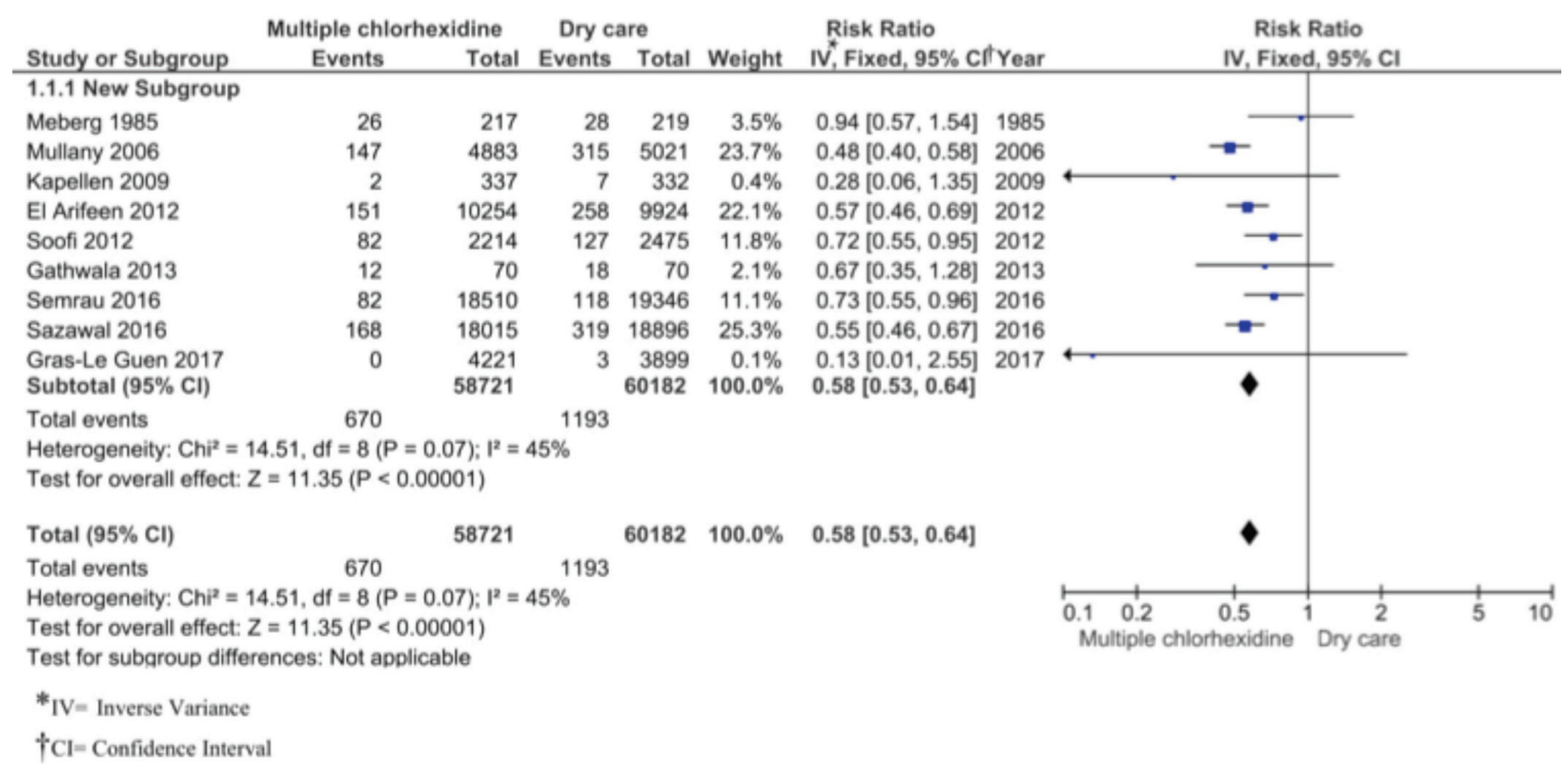

Figure 4 - Omphalitis: Chlorhexidine vs Dry care

When a subgroup analysis was performed, it is observed that in countries with $\mathrm{NMR}<10$ there was a RR of 0.80 (CI: $0.5-1.28$ ), so there are no significant differences between the two types of care for prevention of omphalitis. However, there is a significant decrease in the risk of omphalitis in the subgroup with NMR $>10$
$(R R=0.57, C I: 0.52-0.63)$, as show in Figure 5 . Countries with $N M R<10$ are those in which the studies are conducted with NB older than 36 weeks. According to the GRADE system, the level of evidence is moderate for those studies with NMR $>10$ and low for the present research with $\mathrm{NMR}<10$. 


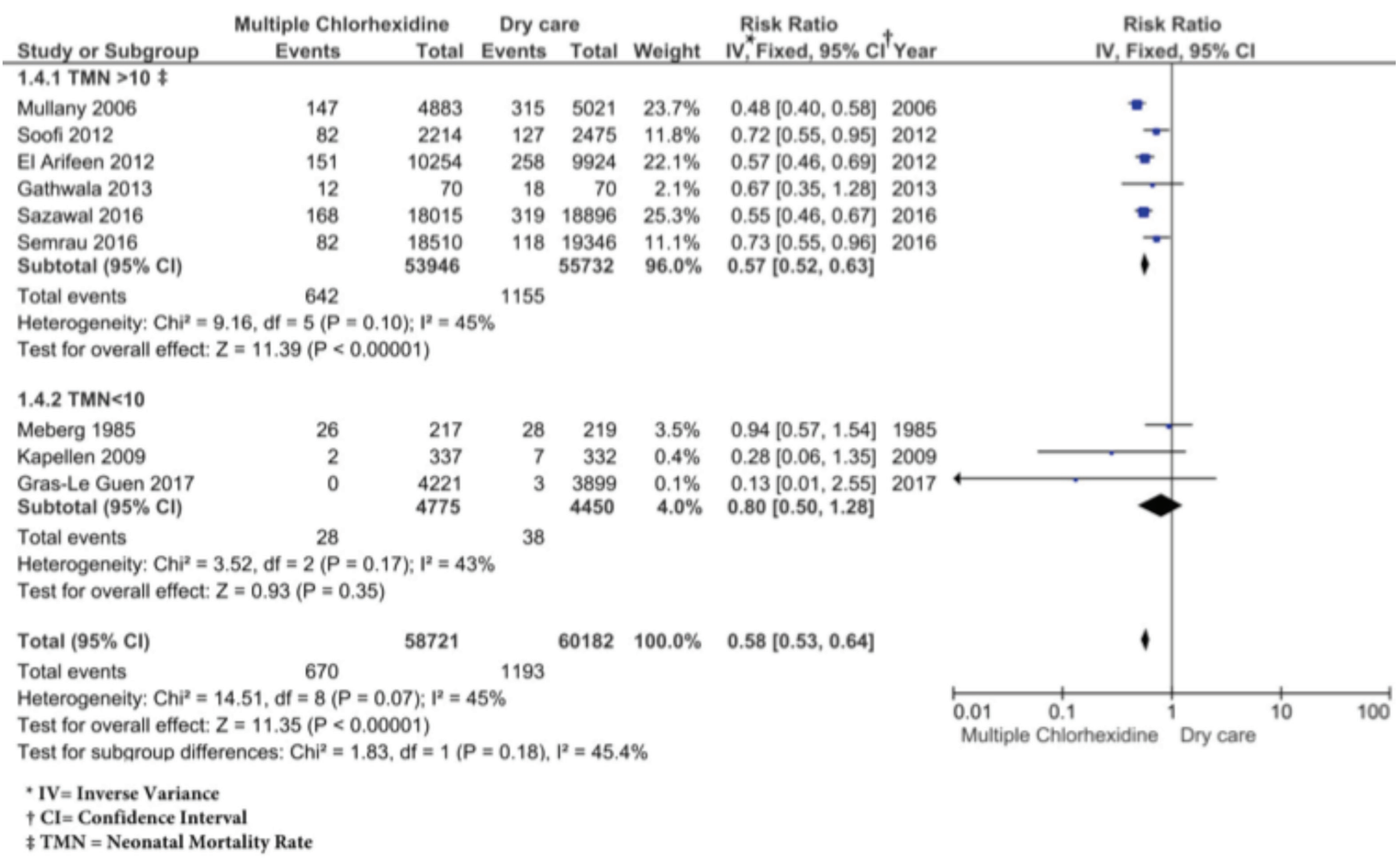

Figure 5 - Omphalitis: Chlorhexidine vs Dry care, according to the Neonatal Mortality Rate

In the community births group there is a significant decrease in the risk of omphalitis using chlorhexidine for umbilical cord care ( $R R=0.57, \mathrm{CI}$ : 0.51-0.62), and a moderate heterogeneity of data was obtained $\left(\mathrm{I}^{2}=45 \%\right.$, $\chi^{2}=7.3, p=0.12$ ). In the community births group there is a significant decrease in the risk of omphalitis using chlorhexidine for UC care ( $R R=0.57, \mathrm{CI}: 0.51-0.62)$, and a moderate heterogeneity of data was obtained $\left(\mathrm{I}^{2}=45 \%\right.$, $\left.\chi^{2}=7.3, p=0.12\right)$. These data from the meta-analyzes by subgroups correspond to a level of evidence rated as moderate, according to the GRADE system.

The sensitivity analysis shows that the risk of omphalitis remains the same for all studies by excluding the studies in which blinding is not performed $(R R=0.54$, CI: 0.47-0.61). When studies not presenting selection bias are analyzed, the risk increases, but there is still a significant decrease in the risk of omphalitis with the use of chlorhexidine for UC care ( $R R=0.63, C I$ : 0.55-0.72), and in this case, the statistical heterogeneity obtained is low $\left(\mathrm{I}^{2}=23 \%\right)$. When sensitivity was analyzed by eliminating studies, it is observed that if a study is eliminated ${ }^{(22)}$, the resulting relative change is $6.18 \%$, and this is the research whose confidence interval is more distant from 1.

Regarding the different concentrations of chlorhexidine used in the studies, when the metaanalysis is performed only with the studies in which a $4 \%$ chlorhexidine concentration was used in the intervention group, the result is a $\mathrm{RR}=0.58$; CI: $0.53-0.64$. By jointly analyzing the studies in which concentrations lower than
$4 \%$ were used, a $R R=0.55$ is obtained; $C I: 0.31-1$. The high heterogeneity of the studies prevents an independent analysis for chlorhexidine concentrations of $1 \%$ and $2.5 \%$.

\section{Discussion}

In a joint analysis, with the inclusion of the latest published studies, the current evidence showed a significant decrease in the risk of omphalitis with the use of multiple applications of chlorhexidine when compared with dry cord care. In countries with high neonatal mortality rates, such as Nepal, with 22 deaths per 1,000 live births(31), the risk of omphalitis is lower with the application of chlorhexidine when compared with dry cord care. In contrast, in countries with very low neonatal mortality rates, such as Germany, with 2 deaths per 1,000 live births ${ }^{(31)}$, application of chlorhexidine does not differ from dry care in relation to the risk of omphalitis, although these studies investigated a small sample when compared with those whose NMR $>10$.

The results also show that community births present a lower risk of omphalitis with the application of chlorhexidine, a finding that corroborates the data from a review conducted in 2015, in which $R R=0.48$; $\mathrm{CI}$ : $0.4-0.57^{(32)}$, and from another one carried out in 2016, in which $\mathrm{RR}=0.4 ; \mathrm{CI}: 0.25-0.63$, with an $\mathrm{I}^{2}$ of $68 \%{ }^{(33)}$. This situation is not consistent with the findings of studies with a group of hospital births, in which there were no differences between the application of chlorhexidine and dry care. The findings of other 
studies also do not show differences in the incidence of omphalitis depending on the type of cord care, although they did not compare solely dry care with the application of chlorhexidine(32-33) for UC care.

Several systematic reviews have shown similar results, in which chlorhexidine was found to reduce the risk of omphalitis(33-35), especially in countries with high NMR. In this sense, our results support that UC care with the use of $4 \%$ chlorhexidine protects against omphalitis in home births in countries with high NMR. The application of chlorhexidine in concentrations lower than $4 \%$ did not act as a protection factor against omphalitis, although it must be emphasized that the studies using these concentrations of chlorhexidine evaluated hospital births.

Depending on where the birth takes place, the UC cutting technique is performed with the use of a new or boiled razor blade ${ }^{(35-36)}$, and this, together with the lack of hand washing before the intervention ${ }^{(35)}$ increases the risk of infection, especially in home deliveries. Researchers are aware that efforts to promote hand washing, cut the umbilical cord with the use of clean instruments and avoid unclean domestic interventions can reduce exposure to infectious agents and improve neonatal outcomes ${ }^{(37)}$.

Limitations: This systematic review with metaanalysis needs to be interpreted with caution due to the included clinical trials and their own limitations. In at least 5 of these studies, it was not possible to mask the intervention of participants and professionals, although it is unlikely that the results were biased, as proven by the sensitivity analysis.

There is variation in the interventions carried out in the different studies such as: in 4 research studies(22,25,27-28), training was provided to the mothers so that they could perform a correct hand hygiene. Regarding hygiene for cutting of the UC, 5 studies $^{(22,24-25,27-28)}$ specify that a delivery kit was given to achieving maximum cleanliness.

There were 3 studies $^{(22,24,25)}$ in which the delivery took place in community settings, 2 in community and hospital settings(27-28) and four in hospital settings $\mathbf{s}^{(21,23,26,29)}$.

In 6 studies, the chlorhexidine concentration used for cord care was 4\%(21-22,24-25,27-28), and the concentrations used in the remaining three studies ${ }^{(23,26,29)}$ were $2.5 \%$ and $1 \%(23,26,29)$. The sensitivity analysis performed considering the different chlorhexidine concentrations used, suggests that the use of chlorhexidine in concentrations lower than $4 \%$ is not associated with a greater protection against omphalitis than that provided by dry umbilical cord care.

Another limitation of the present analysis is that no data on low birth weight and premature babies are shown. The analysis only used data available from studies whose inclusion criteria specified NB at more than 36 weeks gestation.

The criteria used to perform the analysis on the studies classifying omphalitis into several categories were: Redness with pus or severe redness and severe redness with pus, which correspond to moderate and severe omphalitis.

There is no conflict of interest or funding in this study.

\section{Conclusion}

Application of $4 \%$ chlorhexidine in NB significantly decreases the incidence of omphalitis in home births in countries with a NMR higher than 10 deaths per 1,000 live births. The inclusion of newly published studies reinforces the level of evidence so that the use of chlorhexidine is recommended for UC care in developing countries. This meta-analysis provides important information for the policies aiming at the care for NB in home births and in high-risk situations where hygiene conditions are not appropriated.

There are no significant differences between dry cord care and the use of chlorhexidine in concentrations lower than $4 \%$ for UC care in countries with low NMR and in hospital births. It was evidenced that dry cord care is an effective intervention in these contexts and it may be recommended for prevention of omphalitis because it is less expensive. Therefore, it is convenient to expand the knowledge through double blind clinical trials in these contexts to evaluate both interventions and thus improve the care practice provided to the newborn.

In full term NB, there are no statistically significant differences between the two groups of UC care. It is necessary to carry out more studies according to the gestational age to know what proportion of preterm newborns have omphalitis regardless of the type of cord care.

It would be useful to conduct studies with qualitative methodology to know the experiences in the UC care and consider them for the development of more effective and efficient health strategies aiming at reducing the incidence of omphalitis.

\section{References}

1. Karumbi J, Mulaku M, Aluvaala J, English M, Opiyo N. Topical Umbilical Cord Care for Prevention of Infection and Neonatal Mortality. Pediatr Infect Dis J. 2013; 32:78-83. doi: 10.1097/INF.0b013e3182783dc3.

2. Pérez MM, Berasategui HK. [Clinical and epidemiological characterization of omphalitis in a neonatology service]. Medicentro Electrónica [Internet]. 2015 Sep [cited 2017 Feb 28];19(3):157-9. Available from: http:// 
scielo.sld.cu/scielo.php?script=sci_arttext\&pid=S102930432015000300004\&lng=es.

3. Sawardekar KP. Changing spectrum of neonatal omphalitis. Pediatr Infect Dis J. 2004;23(1):22-26. doi:10.1097/01.inf.0000105200.18110.1e.

4. Sánchez-Luna $M$, Pallás-Alonso $C R$, Botet-Mussons F, Echániz Urcelay I, Castro Conde JR, Narbona E. [Recommendations for the care of the healthy normal newborn at delivery and during the first postnatal hours]. An Pediatr. (Barc). 2009;71:349-61. doi: 10.1016/j. anpedi.2009.07.012.

5. Covas MC, Alda E, Medina MS, et al. [Alcohol versus bath and natural drying for term newborns' umbilical cord care: a prospective randomized clinical trial]. Arch Argent Pediatr. [Internet]. 2013 [cited 2016 May 1]; 84: 57-66. Available from: http://www.scielo.org.ar/scielo.php?script=sci_ arttext\&pid=S0325-00752011000400005\&lng=es.

6. Quattrin R, Iacobucci K, De Tina AL, Gallina L, Pittini C, Brusaferro S. 70\% Alcohol Versus Dry Cord Care in the Umbilical Cord Care: A Case-Control Study in Italy. Medicine. (Baltimore) [Internet]. 2016 [cited 2016 jul 20];95:e3207. Available from: https://www.ncbi.nlm. nih.gov/pmc/articles/PMC4998765/. doi: 10.1097/ MD.0000000000003207.

7. Golombek SG, Brill PE, Salice AL. Randomized trial of alcohol versus triple dye for umbilical cord care. Clin Pediatr. 2002;41:419-23. doi: 10.1177/000992280204100607.

8. Suliman AK, Watts $H$, Beiler J, King TS, Khan S, Carnuccio $\mathrm{M}$, et al. Triple dye plus rubbing alcohol versus triple dye alone for umbilical cord care. Clin Pediatr. 2010;49:45-8. doi: 10.1177/0009922808329455.

9. Moher D, Liberati A, Tetzlaff J, Altman DG; PRISMA Group. Preferred reporting items for systematic reviews and meta-analyses: the PRISMA statement. PLoS Med. 2009 Jul 21;6(7):e1000097. doi: 10.1371/journal. pmed.1000097.

10. Cobos-Carbó A, Augustovski F. [CONSORT 2010 Declaration: Updated guideline for reporting parallel group randomised trials]. Med Clin (Barc). 2011;137: 213-5. doi: 10.1016/j.medcli.2010.09.034

11. 11. GRADEpro [Computer program on www.gradepro. org]. McMaster University; 2016.

12. Higgins JP, Thompson SG, Deeks JJ, Altman DG. Measuring inconsistency in meta-analyses. BMJ (Clinical research ed) [Internet]. 2003 [cited 2016 jun 20];327:557-60. Available from: http:// www.ncbi. nlm.nih.gov/pmc/articles/PMC192859/. doi:10.1136/ bmj.327.7414.557.

13. The Cochrane Collaboration. Review Manager (Version 5.3) [Computer software], The Cochrane Collaboration: Copenhagen, Denmark, 2014.

14. Xunta de Galicia. Organización Panamericana de la Salud. Epidat 3.1. Santiago de Compostela: Xunta de Galicia, OPS; 2006.
15. Guala A, Pastore G, Garipoli V, Agosti M, Vitali M, Bona $G$. The time of umbilical cord separation in healthy full-term newborns: A controlled clinical trial of different cord care practices. Eur J Pediatr. 2003;162:350-1. doi: 10.1007/s00431-003-1174-2.

16. Mullany LC, Saha SK, Shah R, Islam MS, Rahman $M$, Islam $M$, et al. Impact of $4.0 \%$ chlorhexidine cleansing of the umbilical cord on mortality and omphalitis among newborns of Sylhet, Bangladesh: design of a community-based cluster randomized trial. BMC Pediatrics. [Internet]. 2009 [cited 2017 Jul 20];9:1. Available from: https://www.ncbi. nlm.nih.gov/pmc/articles/PMC2770449/. doi: 10.1186/1471-2431-9-67.

17. Osrin D. Application of chlorhexidine to the umbilical cord after birth in low-income settings: Two randomised controlled trials. Arch Dis Child Educ Pract Ed. 2012;97:236-7. doi: 10.1136/ archdischild-2012-302621.

18. Bain J. Midwifery: umbilical cord care in pre-term babies. Nurs Stand. 1994;8:32-6. Available from: https://www.ncbi.nlm.nih.gov/pubmed/8123509.

19. Mullany LC, Darmstadt GL, Khatry SK, LeClerq SC, Katz J, Tielsch JM. Impact of umbilical cord cleansing with $4.0 \%$ chlorhexidine on time to cord separation among newborns in southern Nepal: a cluster-randomized, community-based trial. Pediatrics. [Internet]. 2006 [cited 2017 Jan 21];118:1864-71. . Available from: http://pediatrics.aappublications.org/ content/118/5/1864

20. Mullany LC, Shah R, El Arifeen S, Mannan I, Winch PJ, Hill A, et al. Chlorhexidine cleansing of the umbilical cord and separation time: a cluster-randomized trial. Pediatrics. 2013;131:708-15. doi: 10.1542/ peds.2012-2951.

21. Meberg A, Schøyen R. Bacterial colonization and neonatal infections. Effects of skin and umbilical disinfection in the nursery. Acta Paediatr Scand. 1985;74:366-71. Available from: https://www.ncbi.nlm. nih.gov/pubmed/3890463.

22. Mullany LC, Darmstadt GL, Khatry SK, Katz J, LeClerq SC, Shrestha S, et al. Topical applications of chlorhexidine to the umbilical cord for prevention of omphalitis and neonatal mortality in southern Nepal: A community-based, cluster-randomised trial. Lancet [Internet]. 2006 [cited 2017 Jan 21];367:910-8. Available from: http://www.thelancet.com/journals/ lancet/article/PIIS0140-6736(06)68381-5/fulltext

23. Kapellen TM, Gebauer CM, Brosteanu O, Labitzke B, Vogtmann C, Kiess W. Higher rate of cord-related adverse events in neonates with dry umbilical cord care compared to chlorhexidine powder. Results of a randomized controlled study to compare efficacy and safety of chlorhexidine powder versus dry care 
in umbilical cord care of the newborn. Neonatology. 2009;96:13-8. doi: 10.1159/000200165.

24. Arifeen SE, Mullany LC, Shah R, Mannan I, Rahman SM, Talukder M, et al. The effect of cord cleansing with chlorhexidine on neonatal mortality in rural Bangladesh: a community-based, cluster-randomised trial. Lancet. 2012;379:1022-8. doi: 10.1016/ S0140-6736(11)61848-5.

25. Soofi S, Cousens S, Imdad A, Bhutto N, Ali N, Bhutta $Z A$. Topical application of chlorhexidine to neonatal umbilical cords for prevention of omphalitis and neonatal mortality in a rural district of Pakistan: A communitybased, cluster-randomised trial. Lancet. 2012;379:102936. doi: 10.1016/S0140-6736(11)61877-1.

26. Gathwala G, Sharma D, Bhakhri BK. Effect of topical application of chlorhexidine for umbilical cord care in comparison with conventional dry cord care on the risk of neonatal sepsis: A randomized controlled trial. J Trop Pediatr. 2013;59:209-13. doi: 10.1093/tropej/fmt003.

27. Semrau KE, Herlihy J, Grogan C, Musokotwane $\mathrm{K}$, Yeboah-Antwi K, Mbewe R, et al. Effectiveness of $4 \%$ chlorhexidine umbilical cord care on neonatal mortality in Southern Province, Zambia (ZamCAT): a cluster-randomised controlled trial. Lancet Glob Health. 2016;4(11):e827-e36. doi: 10.1016/ S2214-109X(16)30215-7.

28. Sazawal S, Dhingra U, Ali SM, Dutta A, Deb S, Ame SM, et al. Efficacy of chlorhexidine application to umbilical cord on neonatal mortality in Pemba, Tanzania: a community-based randomised controlled trial. Lancet Glob Health. 2016;4:e837-e44. doi: 10.1016/ S2214-109X(16)30223-6.

29. Gras-Le Guen C, Caille A, Launay E, Boscher C, Godon N, Savagner C, et al. Dry Care Versus Antiseptics for Umbilical Cord Care: A Cluster Randomized Trial. Pediatrics. [Internet]. 2017 [cited 2017 jan 21];139:e20161857. Available from: https://www. ncbi.nlm.nih.gov/pubmed/28008096. doi: 10.1542/ peds.2016-1857.

30. Egger M, Davey Smith G, Schneider M, Minder C. Bias in meta-analysis detected by a simple, graphical test. BMJ. 1997; 315:629-34. doi: https://doi. org/10.1136/bmj.315.7109.629

31. The World Bank: Mortality rate, neonatal (per 1,000 live births) [Internet]. Washington, DC: The World
Bank; [cited 2016 Oct 15]. Available from: https://data. worldbank.org/indicator/SH.DYN.NMRT?view=chart.

32. Sinha A, Sazawal S, Pradhan A, Ramji S, Opiyo $N$. Chlorhexidine skin or cord care for prevention of mortality and infections in neonates. Cochrane Database Syst Rev. [Internet]. 2015 [cited 2016 May 20];3: CD007835. Available from: http://onlinelibrary.wiley. com/doi/10.1002/14651858.CD007835.pub2/abstract ; jsessionid=9BD87C03C0A9A7B4E96E7985B6A40E47. f04t02. doi:10.1002/14651858.CD007835.pub2.

33. Shariff JA, Lee KC, Leyton A, Abdalal S. Neonatal mortality and topical application of chlorhexidine on umbilical cord stump: a meta-analysis of randomized control trials. Public Health. .2016;139:27-35. doi: 10.1016/j.puhe.2016.05.006.

34. Imdad A, Mullany LC, Baqui AH, El Arifeen S, Tielsch JM, Khatry SK, et al. The effect of umbilical cord cleansing with chlorhexidine on omphalitis and neonatal mortality in community settings in developing countries: a meta-analysis. BMC Public Health. [Internet]. 2013 [cited 2016 Oct 21];13:1. Available from: https:// www.ncbi.nlm.nih.gov/pmc/articles/PMC3847355/. doi: 10.1186/1471-2458-13-S3-S15

35. Penfold S, Hill Z, Mrisho M, Manzi F, Tanner M, Mshinda $\mathrm{H}$, et al. A large cross-sectional communitybased study of newborn care practices in southern Tanzania. PLoS One. [Internet]. 2010 [cited 2016 May 20];5:e15593. Available from: https://www.ncbi.nlm. nih.gov/pmc/articles/PMC3006340/ doi: 10.1371/ journal.pone.0015593.

36. Amare Y. Umbilical cord care in Ethiopia and implications for behavioral change: a qualitative study. BMC Int Health Hum Rights. [Internet]. 2014 [cited 2016 May 20]:14:12. Available from: https://www. ncbi.nlm.nih.gov/pmc/articles/PMC4021177/ doi: 10.1186/1472-698X-14-12.

37. Alam MA, Ali NA, Sultana N, Mullany LC, Teela KC, Khan NU, et al. Newborn umbilical cord and skin care in Sylhet District, Bangladesh: Implications for promotion of umbilical cord cleansing with topical chlorhexidine. J Perinatol. 2008; 28(Supl 2): 61-8. doi: 10.1038/ jp.2008.164. 